\title{
PARTITION AND THE RISE OF HINDUTVA MOVEMENT IN CONTEMPORARY INDIA
}

\author{
Bhagwan Josh \\ Jawaharlal Nehru University, Delhi
}

\section{Abstract}

Hindutva movement is now actively seeking to capture instruments of state power and trying to impose its cultural hegemony by mobilizing Hindus. In post-Independent India, the Hindutva movement has reached such proportions because the much desired 'left-of-centre' consolidation failed to emerge in the 1970s and 1980s. Over these decades, the governments of the day claimed that India was a secular country but in actual practice, because of the fear of losing Muslim votes, they constantly postponed the implementation of a secular agenda thereby opening the space for the Hindutva forces to rush in. Now the political terrain has changed drastically. Is the belief that a multi-religious and culturally diverse society can wield itself into a nation and democratic polity coming apart? Is the sub-continent returning to the European model of building ethnic nation-states underpinned by the cultural codes of a mono-culture or single religion? In a line, could this be attributed to the 'long shadow' of the Partition of India?

KeYwords: BJP, Cultural hegemony, Hindutva, RSS, Secularism, Two-nation theory.

\section{Resumen}

Hindutva persigue, mediante la agitación entre hindúes, controlar los resortes del poder e imponer la uniformidad cultural. En parte esta preponderancia de Hindutva se debe al fracaso del "centro-izquierda" para consolidarse como fuerza política en las décadas de 1970 y 1980. A lo largo de este tiempo los gobiernos de turno se proclamaban laicos, pero se inhibían de acometer políticas en ese sentido para no perder apoyo entre los musulmanes, lo que ha permitido que el extremismo hindú capitalizara la oposición. En estos momentos el panorama ha cambiado de forma drástica. ¿¿Puede una sociedad multirreligiosa y multicultural desarrollarse en un estado en descomposición? ¿El subcontinente se está asimilando al modelo europeo de la nación-estado étnica, apoyada en una religión y una cultura exclusivas? En otras palabras ¿es esto una consecuencia de la Partición?

Palabras clave: BJP, Hegemonía cultural, Hindutva, Laicismo, RSS, Teoría de los dos estados-nación. 
Since 2014,after it has been able to successfully form the Government at the centre, Hindutva movement (an exclusivist variety of Hindu nationalisms that seeks to construct Indian nation in a supremacist vision) has been actively seeking to capture instruments of state power and simultaneously trying to impose its cultural hegemony by mobilizing Hindus, especially the youth, on the issues of cow-slaughter, beef-eating, terrorism in Kashmir and the tensions with Pakistan, conversions to other religions, singing of the national song Vande Matram (hail the motherland), and above all, the longstanding issue of constructing the Ram temple in Ayodhya, at the exact site where Hindu idol Ram has supposed been born centuries ago. Twenty-five years ago, on $6^{\text {th }}$ December,1992, three domes of a medieval mosque in a Uttar Pradesh town came crashing down. Throughout the $20^{\text {th }}$ century, extremist varieties of Hindu nationalism have fought a long battle to change the cultural complexion of the nation. However, during the struggle for India's independence, this movement has been running parallel to the mainstream anti-imperialist movement led by the Indian National Congress and M.K. Gandhi. The Partition of India provided it a new fuel of tremendous anti-Muslim sediment hatred. As millions of Hindu and Sikh refugees began to pour in India by crossing the hurriedly drawn border, a new political climate of anger began to be built up against the Congress leadership, especially against Gandhi, who was seen as still being sympathetic to the Muslims. This is what Nathu Ram Godse explained his action to the trial court, embodying the frustration and anger of millions of Hindus:

I do say that I had no respect for the present Government owing to their policy which was unfairly favourable to the Muslim. At the same time I could clearly see that the policy was entirely due to the presence of Gandhiji. In the absence of such pressure the way is now open for the establishment of a secular State in the true sense of the word. I have to say with great regret that the hon'ble Prime Minister Nehruji quite forgets that his actions and deeds are at times opposed to each other, when he talks about secular State in season and out of season; because it is significant to note that the hon'ble Pandit Nehruji has himself taken a leading part in acquiescing to the establishment of Pakistan, a theocratic State. But he should have realized that it will never bring prosperity to Indian Union with a State founded on fanatically blind religious faith and basis by its side. After having considered absolutely to myself, my mind impelled me to take the action against Gandhiji. (Godse, par. 48)

The Partition of the sub-continent along religious lines convinced the extremist Hindu nationalists that since Pakistan was a Muslim nation, India should be a Hindu nation. Sections of this movement have continued to believe and preach that Indian Muslims are inheritors of a historical tradition of violence by Muslim kings. They have their own understanding of India's "medieval" past which is dubbed as inaccurate and distorted history by self-proclaimed "secular historians". In the conquest of the demolition of a mosque for them, which carried the name of the first Mughal emperor, the celebrations after the demolition appeared to settle multiple 
scores. All the Muslims in India did not descend from the Muslim aristocracy, which came from other countries and made India their home. It is generally believed that about 9 out of 10 of them are converts from low-caste Hindus who were attracted to Islam's message of equality. As opposed to the view of secular historians, sections of the Hindutva movement continue to believe that those conversions of the past were forced conversions and were inimical to the organic and natural evolution of Hindu society. Hence, its agenda to stop conversions to Christianity and Islam in post-independent India by various means, including violent means. For them denationalised Christianity and Islam continue to pose serious threat even today and the only way to handle this threat was the creation of a Hindu Rashtra. This agenda, with the complicity of local police, takes the form anti-Christian violent activities at the grassroots level. The anti-conversion agenda, it must be remembered, has legal cover in Madhya Pradesh: sweeping provisions in the Madhya Pradesh Freedom of Religion Act,1968, allow police to criminalize conversion (Josh 2009: 97-115).

The partisan ideological notions of the vigilante groups such as "ghar-vapsi" (reconversions to Hinduism) and "love-jihad"(discussed below) are attempts to create in Hindu society a strong awareness to stop such conversions and (crossing over Hinduism's boundaries by young women to non-Hindu cultural enclosures). For them state's efforts to remove poverty through economic development is not enough. The state in independent India (also must become a cultural state). For secularists the idea of such conversions to other non-Hindu religions is blown out of proportion and devised to mislead the people. Moreover, keeping in view the colonial and Congress traditions, India's multi-culturalism must be allowed to remain intact and the Indian state must remain neutral in religo-cultural mattes.

For the extreme Hindu nationalist forces, the Muslims who had stayed back after the Partition, irrespective of the Constitution, in actuality, have forfeited their right to Indian citizenship as the new state of Pakistan was demanded in the name of Islam and on behalf of all the Muslims of the Indian subcontinent. The Partition had been agreed to by the Congress leaders on the basis of religion. Therefore, the other half of the state, comprising the Indian territory, must now be logically considered and also must existentially become, a Hindu state. This was the agenda of extreme Hindu nationalism since 1930s and the movement embodying it continued to persist as a marginal political force till 1970s. To its credit, the leaders of this movement stood for democracy and opposed the Emergency by Indira Gandhi in 1975.This was the moment that the RSS was waiting for, to wash the stain of Gandhi's murder and acquire the political respectability to enter the mainstream of India's political life. This led to a sudden turn in its fortunes as it became a part of the Government at the Centre for the first time in 1977, a politically centrist Government that was also supported by the Communists.

In the 1980s, the Sangh Parivar, a network of Hindu organisations, sought a new symbol to stir up the Hindu nationalist fervor. It began to actively align itself with the movement seeking to build a grand temple to Hindu God Ram at the exact site where a Mosque built by the Mughal emperor Babur stood. In actuality, the demand was based on the "fact" of belief of Hindu masses ( Hindu astha), and from the very beginning, was cast in the form of a trial of strength between India's 
two broad cultural forces-one proclaiming secularism and other extreme Hindu nationalism.

On December $6^{\text {th }} 1992$, the demolition of a dilapidated mosque - known as Mosque - was announced to the world by the BBC correspondent: "Hindus have done something which they had not done in the last five hundred years." This was the first moment of decisive triumph for this movement. The politicians who had been leading this movement have not looked back since then. A decade after the demolition of the mosque, the Bhataiya Janata Party (BJP) came to power at the Centre and it decided that for V.D. Savarkar's ideology i.e. Hindutva, be officially recognised, a due ceremony was in order. By 2003, Savarkar's dream of making India a Hindu nation had finally been moving towards its partial fulfillment. It decided to place Savarkar's portrait in Parliament House's Central Hall, along with portraits of the greats of India's freedom struggle. The shunned, if not hated, ideological variety of Hindu nationalism, and its main articulator despised by many, had finally arrived on the Centre stage of Indian politics. Just like Jinnah, Savarkar had believed that Hindus and Muslims formed Two Nations. Jinnah realized his goal with Partition. Savarkar did not, could not, for India chose to follow Gandhi, Nehru and the Congress. Let it be added here, according to the Kapur Commission of Inquiry Report constituted in 1969, Nathuram Godse had a long meeting with Savarkar on January 23 or 24, before he returned to Delhi and shot Gandhi thrice at point-blank range on January $30^{\text {th }}$ 1948.Savarkar was arrested in connection with a conspiracy to kill Gandhi. But there was no direct evidence to legally prove criminal conspiracy. The judge found it "unsafe" to convict Savarkar. Godse and Narayan Apte were awarded death penalty but Savarkar was acquitted.

But the rise of forces of extremist Hindu nationalism were immediately preceded by two other political developments known as-Mandal Commission and L.K. Advani's Rath Yatra of 1990. Both were closely linked with each other. The Mandal Commission was established in India on $1^{\text {st }}$ January 1979. In 1980, the Commission recommended that members of other backward classes (OBC) be granted reservations to 27 percent of jobs under the central government and public sector undertakings. The Report became the site of sharp political contest when the National Front government under V.P. Singh decided to implement this recommendation of the Report in August 1990. The BJP, which was part of this government, perceived it as a deliberate attempt to encourage the identity politics of caste, thereby undermining its ideology of organic Hindu society and denial of primacy of Hindu nationalism over the divisive politics of caste identities. Thousands of young men flocked to Advani's call, forming the bands of volunteer army which sought to demolish the Masjid unsuccessfully in October 1990, before achieving this 'success' two years later. BJP leader L.K. Advani travelled across the country in a chariot from Somnath temple, a temple which had been plundered by the Turk invader Ghazni in 1024, symbolising the crimes of Muslim rulers. Anti-Muslim sentiments were roused to a fever pitch throughout this journey, peaking at levels unsurpassed since the Partition riots.

Preceding and following the demolition of the Babri Masjid were a series of riots, in which thousands of innocent Indians lost their lives. No single event 
in independent India has so polarized public opinion; no single event so adversely affected life on the ground, generating widespread suspicion and hostility between groups of citizens — and leading to much violence and suffering too. Today, there are violence-oriented young vigilante groups in various parts of the country which are still continuing to raise the slogans, day in and day out: 'Musalman kay do hee sthaan, Pakistan ya qabristhan'(there are only two places for Muslims - Pakistan or the graveyard. $)^{1}$ Stray incidents of mobs lynching Muslims do form a clear pattern to send the message that Muslims should know their place, that of second-class citizens. All those secularists who were egging on the Muslim leadership not to compromise with Hindus on cultural issues of conflict are now nowhere to be seen. No wonder, a sense of terror has gripped the Indian Muslims. Almost all the leading newspapers are telling the government and the leaders of the BJP to be mindful of their agenda of building a grand temple in Ayodhya before the parliamentary elections of 2019. A long quotation from the editorial of a very important daily will be in order here:

Priests of several akharas in Ayodhya, who clearly have no notion of what spirituality means, have served an 'ultimatum' to BJP to build a Ram temple at the site of the demolished Babri Masjid as a way of 'avenging' the deaths of Karsevaks in Godhra in2002. But the politics of revenge has already caused devastating riots in Gujarat after Godhra -indeed all communal riots are motivated by a similar politics of revenge. It's a new century now and the country is striving to move past this legacy of violence and bloodshed, stemming from the 1947 Partition, towards a future of peace, development and prosperity. In the words of Prime Minister Narendra Modi: 'sab ka saath, sab ka vikas.' Attempts to disinter the ghosts of the past, therefore, must be resisted at all costs. The demolition of the Babri Masjid itself was a criminal act to which political authorities turned a blind eye, out of the mistaken notion that nebulous entities such as hypothetical 'community sentiment' should gain precedence over the rule of law and constitutional values such as equality and religious liberty. Once enshrined, such a notion will become a principle of instability and anarchy, subverting democracy itself; India will come to resemble neighbouring Pakistan. ("Old obessions" 2017).

The series of events that led up to the demolition in December 1992, began with the Shah Bano case. In 1978, sixty two years old Shah Bano Begum of Indore was driven out of her matrimonial house by her husband. When Shah Bano sought maintenance under CRPC, section 125, her husband divorced her by resorting to the practice triple talaq (divorce). Not only that, her husband Mohammed Ahmad Khan, refused to provide her and her five children promised maintenance of Rs. 500. Various court judgments upheld the right of Shah Bano to monthly maintenance. Rajiv Gandhi came to power in 1984 after the assassination her mother Indira

1 At many religious places anti- Christian and anti-Muslim slogans could be found written on the walls. For example these were the slogans on the walls of Shabri temple in Gujarat's conflict ridden tribal district Dangs: Hindu jagao, Christi bhagao (awaken the Hindus and force the Christian missionaries to run away). 
Gandhi. Under pressure from Muslim hardliners, his Government enacted a Law in Parliament that overturned the Supreme Court judgment in the Shah Bano case. The 1986 Muslim Women (Protection on Rights of Divorce) Act diluted the Supreme Court judgment and allowed maintenance to a divorced woman only during the period of iddat or till 90 days after the divorce. More importantly, this was done after Muslim leaders protested that the judgment encroached upon the right of the community to be governed by its personal laws. This was widely seen as an appeasement of Muslim orthodoxy and betrayal of the promise of implementation of Uniform Civil Code made in the Constitution. This offended many Muslim and Hindu supporters of the Congress and exposed the hollowness of its ideology of secularism. It was widely believed that Rajiv Gandhi overturned the Shash Bano judgment for fear of losing the Muslim vote. The BJP had strongly criticized the "appeasement" of Muslims. In order to pacify the anger of the Hindus, the gates of the Babri Masjid were unlocked and, three years later, at the end of Rajiv's tenure, the Vishav Hindu Prishad (VHP) was allowed to carry out the Shilanyas (to lay foundation) for the construction of Ram temple. The practice of instant triple talaq continued and in August 2017, ShayaraBano and four other women won their case in the Supreme Court. An overwhelming majority of Muslim women wanted an end to practices such as talaq-e-biddat (instant triple talaq), halala (wherein a Muslim woman if she wants to remarry her divorced husband, must first consummate her marriage with another man) and polygamy. On August $22^{\text {nd }} 2017$, thirty-two years after the Shah Bano case, the Supreme Court of India declared that the practice of triple talaq violates the right to equality and is thus against the law. Unlike the Congress Government, the BJP Government is expected to take the triple talaq verdict of the Supreme Court to its logical conclusion by framing a very stringent law whereby the government plans to make triple talaq a crime punishable with three years in jail and a fine as a "necessary deterrent." Many Muslim organisations have denounced it as a vicious ploy of the BJP government to criminalise Muslim men. ${ }^{2}$

${ }^{2}$ In the Shah Bano case [1985(2) SCC 556], the Supreme Court of India had aptly said: "It is also a matter of regret that Article 44 of the Constitution has remained a dead letter. It provides that the State shall endeavor to secure for the citizens a uniform civil code throughout the territory of India'. There is no evidence of any official activity for framing a common civil code for the country. A belief seems to have gained ground that it is for the Muslim community to take the lead in the matter of reforms of their personal law." "A common civil code will help cause of national integration by removing disparate loyalties to laws which have conflicting ideologies. No community is likely to bell the cat by making gratuitous concession on this issue. It is the state which is charged with the duty of securing uniform civil code for citizens of the country and, unquestionably it has the legislative competence to do so. A counsel in the case whispered, somewhat audibly, that legislative competence is one thing, the political courage to use the competence is quite another." Quoted in The Times of India, January $8^{\text {th }} 2017$. 
In today's world, even when nationalism is once again asserting itself and many governments and parties are busy promoting it, there is no dearth of individuals who still feel convinced that the "nations are lines in the sand, tomorrow they may not be there... why would you give up your life for that?" (Rajanit Kath Ganesh 2017). Yet the explosive power of these "lines" continue to create wars in the contemporary world, including the ones in the post-colonial South Asia. W.H. Auden's unsparing poem 'Partition', written in 1966, is a caustic criticism of the five weeks Cyril Radcliffe spent in the subcontinent drawing up the borders between India and Pakistan. And it is this line, known as "Radcliffe Line", which became the immediate cause of an explosion of violence that killed one million people and displaced 12 million. Retrospectively, it has now been universally accepted that "1947" created a cycle of revenge that has resonated through the decades and still plagues the subcontinent. Thus for it has led to three wars, countless acts of terrorism, polarization around the Cold War powers and both nations spending massive amounts on their military while millions live in poverty. The roots of much of today's violence in the region are in the decisions taken that year. Moreover, "this line", has left an unforgettable legacy which continues to cast a long shadow on the daily lives of Indians in many subtle and not so subtle ways. Each year Partition is being remembered in new ways. On $24^{\text {th }}$ October, 2016, the Partition Museum was launched in Amritsar. The latest literary festival in Gurgaon, the place where I live, devoted a special session to "Memories of Partition".In the last few decades, scores of films have been made, novels have been written and plays enacted on the theme of Partition. Also there is a substantial amount of poetry dedicated to this theme. Hardly, a day passes in the lives of the Indian people when some "banal" incident or some statement of an utter "absurdity and stupidity" by some extremist fringe group do not remind Indians of the bitter memories associated with "this line."

With the arrival of a new type of modern colonial state the political power of the erstwhile Muslim rulers was replaced by a new centralised administration based on modern scientific methods. This massive change opened up spaces for the Muslim cultural hegemony, built during the long period of so-called medieval history, to be challenged by the Hindu groups. Thus, towards the end of the $19^{\text {th }}$ century, just thirty years after the great revolt of 1857, India began to be engulfed in massive sectarian riots between the two communities. These peaceful and violent, constitutional as well as non-constitutional, cultural contests on various issues between the Muslim and the Hindu cultural forces were geared towards dismantling the earlier cultural power relations. Even after Partition, this cultural strife has continued intermittently as large number of Muslims had stayed back in India. The rise of the forces of Hindutva were born and nurtured in the interstices created by the continuously occurring violent and peaceful confrontations between sections of the two communities, in this longue duree history.

In post-Independent India, while the nationalists in the Indian National Congress sought to contain these Hindu-Muslim cultural contests within a discourse of democracy and mass representation, sections of the Hindus found in this 
democratic polity an opportunity to argue for an aggressive strategy, to establish Hindu hegemony by mobilizing Hindus on a multi-pronged agenda. One of the leading ideologues of Hindu nationalism, M.S. Golwalkar had defined the 'we' of the future Indian state:

In Hindustan exists and must need exist the ancient Hindu nation and nought else but the Hindu nation... so long, as they (Muslims and other non-Hindus) maintain their racial, religious and cultural differences, they cannot but be only foreigners... There are only two courses open to the foreign elements, either to merge themselves in the national race and adopt its culture, or to live at the sweet will of the national race... they must cease to be foreigners, or may stay in the country, wholly subordinated to the Hindu nation... (Gowalker 19, 52-56, 62).

Since 1940, this theme/idea/ideology of Hindutva has been sought to spread throughout the country by thousands of committed cadres organized into RSS shakhas (groups) through regular meetings, conferences, educational institutions, and hundreds of small and big newspapers. The dissemination of this ideology by various Hindu organisations and personalities has been the subject of scores of academic studies and hundreds of research papers. The long-term impact of Partition is the creation and perpetuation of psychological mindsets where Hindus and Muslims could not be seen as one unified nation and this sediment idea now refuses to be undone through any kind of consensus. What has come to be called as 'Uniform Civil Code' (1985) and 'Ram Janambhoomi Controversy' (1992), along with the recently enacted and zealously imposed laws to protect the 'Gau-mata'(mother-cow) are three prominent issues of durable contention and sectarian social strife. As we would see in the discussion that follows that the cultural contest centering on these three issues, and some other issues indirectly associated with them, instantly invoke the deeper cultural fault-line of longue duree history of Hindu-Muslim relations (Joshi and Josh 1994: vol. 3, chp. 5, 6). The stoking of this fault-line, over the years, has continued to generate immense political energies, violent passions and mass mobilizations which firmly set contemporary India on to a trajectory which has finally brought a pro-Hindu political party (BJP)-into power in 2014. As a result of this continued cultural strife, post-independent India, especially after 1980s, continues to be a battleground of contesting nationalist ideologies, one claiming to be secular and the other labeled and denounced by secularists as "communalism" (Joshi and Josh 2013: vol 3).

Since 1990s, with the background of rising terrorism, a constant war has been going on between the armed groups in Kashmir and the Indian Army; some call it a 'proxy war' between Pakistan and India. The impact of happenings in Kashmir covered by TV channels, print and social media continues to influence the existing mindsets of the Indians. As a result, the day to day cultural-political atmosphere of the country remains surcharged and tension ridden under the surface of an uneasy calm. The cultural project of making India Hindu is being implemented in many ways by the Modi-led Government: from the top by its own carefully designed cultural polices and from the bottom by being complicit with mass agitations and demands in society that are challenging the freedom of expression of poets, writers, 
artists and film makers. As a result of these multi-pronged cultural practices a sort of new Cultural State is being sought by partly dismantling the existing one that has evolved in the last seventy years under the banner of secularism.

In today's India, due to the deepening of cultural divide between Hindus and Muslims, the moral and ethical visions of even the most ideologically neutral individuals are not considered above suspicion by the political parties. Three years ago, the forces professing the idea of 'Hindu Nation' have acquired a position of political dominance by getting about 31 percent of the total votes in the country. Their governments are in power in majorities (29) of the Indian states. But it is still faced with the serious problem: how to translate this dominance into societal hegemony by winning over lower castes and sections of the Muslims, especially women. Only that position could allow them to perpetuate their rule at the Centre in a liberal democratic polity. How far they have actually travelled down that road as for as country as a whole is concerned would be clear only after the general elections of 2019. The BJP is still far from acquiring a cultural status, moral sagacity and political disposition where the majority of the nation is willing to accept it as a trustworthy hegemonic power with a degree of stability and certainty of cultural consolidation.

In October 2001, Narendera Modi became Chief Minister of Gujarat. Because of BJP's longstanding struggle to acquire a solid and stable mass base in this part of India, some journalists have dubbed it as a laboratory of Hindutva. The election results on December $16^{\text {th }} 2017$, have shown that BJP will be forming its Government for the sixth time.

It is in Gujarat that the project of Hindu Rashtra has reached a fairly advanced stage but it still continues to be shaky and unstable because of the challenges posed by large sections of the lower and agrarian middle castes in rural Gujarat who are dissatisfied with the unfulfilled promises of BJP regarding the creation of jobs and relatively high prices for their produce, especially cotton. In fact, this is a pan-Indian problem, inseparably linked to a deepening crisis in the vast agricultural sector: as a result of this crisis thousands of poor peasants have committed suicide throughout India. The BJP has successfully eroded the hegemony of the Indian National Congress but at the same time it is not yet in a position to create an alternative Hindu hegemony by making itself acceptable to majority of the Hindus, especially in rural areas. In the coming two decades, the whole of India is headed towards a permanent social strife in the rural areas where majority of the population lives. It is in this context that all the politically aware Indians are looking towards the results of the Gujarat elections.

The diversity of India is constituted by several divisions based on caste, religion, language, class and region. Political parties have arisen out of these divides and shifting coalitions. Every party needs to create a coalition of vote-banks to win power at the Centre. The BJP has been obliged to woo wide variety of votebanks, especially the lower castes known as Dalits. This is not easy, and the BJP has stumbled badly on the employment front. The current agitations by dominant rural castes - Patidars in Gujarat, Marathas in Maharashtra, Gujjars in Rajasthan and Jats in Haryana-for reservations in government jobs pits them against existing Hindu beneficiaries of reservations (Dalits, tribals, and other backward castes). Thus 
even an economic issue, like employment, gets converted in India into inter-caste rivalry that fragments the Hindu monolith that the BJP would love to create.

The inability of any democratic state to withstand fully or for very long the assertation of a majority culture was revealed of the Indian state from the outset. The natural corollary of this phenomenon was the necessity to tilt towards extra sensitivity to minority culture and the self-representations of leaders of the minorities. This was seen as the essential corrective to attempts by the ideologues of the majority to convert the upswing of cultural assertiveness into culturally aggressive projects striving to establish cultural domination over the minority. On the one hand, this tilt is what has been termed 'appeasement of minorities' by the ideologues of Hindu cultural dominance and on the other upheld as proof of its 'secular' stance by the state leaders of the Indian National Congress. This is how Shashi Joshi has formulated the conflictual trajectory of Political developments in India in 1994:

The battle between revisionist and dogmatic Hinduisms, to define a culturally Hindu India is in full swing under the banner of a confrontation between 'secularism' and 'communalism' whether all its implications are comprehend or not. However, a sizeable segment of Indians is implicated in the cultural hegemony of the West-through colonialism to post-colonial global influences. This segment may not be involved-at least actively or consciously in the old cultural contests of the past that hark back to ancient or medieval history. However, the desire to assert their own cultural significance vis-à-vis the 'west' grips increasing sections of affluent Indians (Hindus, Muslims, Sikhs, etc.) even as they adjust to and emulate Western lifestyles. In this context, a throwback to pre-colonial cultural contests becomes a natural corollary to efforts at defining a cultural 'we' apropos the Western world. The power struggles of today may be between the 'West' and 'India' but the defining of India revives power struggles of the past. The process of so defining becomes an act of power in itself- a strategy for forging the future. It is thus that the past continually intervenes in the present. (Joshi and Josh 1994: vol. 3/360)

For the Sangh Parivar, the 2002 post- Godhra riots marked the apotheosis of the campaign to establish Hindu Rashtra, a time of cultural war when dominance was violently imposed over the 'Muslim other'. But many signs indicate that the twenty years of BJP rule in Gujarat has made the Muslims, ten percent of Gujarati society, completely invisible as the Congress, a party which has ruled over India in the name of 'secularism' was not campaigning in the Muslim areas for the fear of being dubbed as the Party of the minorities/Muslims. Neither has it put up Muslim candidates even as tokenism, an evidence of its 'secular' credentials. The leaders of the Congress Party have come to the conclusion that their Party lost the 2014 parliamentary elections because the BJP was able to convince the liberal Hindus, who have been supporting the Congress all along, that Congress was, in actuality, a Party of the Muslims. Thus the BJP has successfully forced the Congress leadership to abandon its earlier terrain of 'secular politics' and come to BJP's own terrain within Hindu cultural internality. This time the Congress too was fighting to get a bigger chunk of the Hindu votes. Thus, willy-nilly, the Congress has accepted the $\mathrm{BJP}$ assumption, the central plank of its project of Hindu hegemony, that it is only 
the Hindu communities that should matter to decide the nature of political rule in this country. It has agreed with the BJP in openly proclaiming: from now onwards we, both the parties, have agreed to disenfrenchise the Muslim population. As a result of this, the Congress has been quick to take a "strategic Hindu turn." Rahul Gandhi was on a temple-hopping spree and has visited twenty-eight big and small Hindu temples. He offers pooja in an ostentatious way which Congress leaders never did before. By questioning Rahul's identity — "he must say who he actually is"the BJP has challenged him to openly declare his religious affiliation. The implicit message is that Rahul does not deserve to ask for the votes of the Hindus in Gujarat because his Hindu credentials are questionable. Congress, on the other hand, released Rahul's photograph with a janeu-(sacred thread that is worn by Brahmins) to establish that he is a 'janeu-dhari Hindu'.

This debate has disturbed many people who had come to believe that 70 years after independence, one's Indian identity matters less than one's religious identity in an election. The Congress Party, some feel, that keeping in view its claim to being a Secular Party, "should have loudly proclaimed that Rahul Gandhi is a true representative of multi-faith, diverse India. Look at his pedigree. His paternal grandfather was Parsi. His father, thus half-Hindu (Brahmin) and half Parsi, married Sonia, who is Italian and Catholic. Thus Rahul is a Hindu and a Parsi and a Christian Catholic...Has the Congress forgotten the meaning of secularism in its haste to adopt Hindutva line?" (Desai 2017). The Congress Party managers' argument was that Rahul would only play into the BJP's hands if he mentions 2002 Godhara riots or secularism. Wooing the Patidar community is a recognition that the Congress is coming around the view that only caste and not secularism can break the stranglehold of religion and defeat Hindutva. In this new experiment Congress is opposing BJP's Hindutva with its own brand of soft-Hindutva.

Today, Gujarat's religious partition is complete. Every city has a "border", an extension of the 'Radcliffe line' drawn in 1947, an invisible line dividing Hindu and Muslim areas. The BJP has reigned supreme in this urban 'apartheid' for the last two decades.It would be a futile exercise to blame the parties and their leaders to openly display their religious identity. The long-term consequences of the Partition have been constantly at work to create religious polarization in Indian society. In democracies, politicians often mirror the society and times in which they live.

There was another event which pushed the Congress to openly locate itself within the Hindu cultural internality. And that was the massacre of thousands of Sikhs in Delhi after the murder of Indira Gandhi in November 1984. The then Prime Minister Rajiv Gandhi did nothing to stop these killings by the organized Hindu mobs. The wave of sympathy which had given him a massive victory was very deceptive. He was able to win 411 seats out of 542, the largest Lok Sabha majority to date. This wave was also responsible for the BJP's massive defeat when it could muster only 2 seats in 1984. Looking from another point of view, this temporary defeat was in actuality its finest victory as it showed, for the first time, the potential power and aggressiveness of the organised Hindu sentiment. All that was now needed, was its further consolidation and to yoke it to the agenda of Hindu Rashtra. Rajiv Gandhi had miserably failed to keep the Congress Party on its secular track and 
permanently tainted its ideology. He has done for the BJP which BJP could never have achieved through its own efforts. Let it be emphasized that political parties do not capture power of their own. They are always helped by their opponents and contestants in many ways.

\section{PARTITION AND DILEMMAS OF INDIAN SECULARISM}

From the days of its foundation the leaders of the Indian National Congress had posited an a priori separation between 'Hindu cultural nationalism' and 'political nationalism' in order to build a composite anti-imperialist opposition - a nation in its embryonic form - of all the religious communities in the subcontinent. During the period of mass movements (1920-42) and even after independence and Partition the Congress continued to declare its commitment to this a priori separation. It seems, given the cultural diversity, it was difficult for the early nationalist intellectuals to imagine the shaping up of an all-encompassing Indian nation without upholding this assumption. But the kind of cultural issues that emerged and coincided with the establishment of the independent nation-state clearly showed that the relationship between Hindu cultural nationalism, political nationalism and the sphere of state politics was a complex one and the their professed separation could not always be maintained. Some of these issues were the construction of the temple as Somnath, ban on cow slaughter, Hindi as the national language and the Hindu Code Bill which, inadvertently, further underlined the idea of Hindus being a separate community despite their internal differentiation.

Secular historiography has failed to note the important fact that for considerable sections of Indians and the Indian National Congress, '1947' meant not only a moment of political independence but also, to put it in the words of Vivekananda, the foremost cultural ideologue of Hindu nationalism, the end of 'a thousand years of slavery' (Embree 160). For them, it was also a moment of celebrating the cultural pride and glory of the Hindus. But there were others in the Congress, especially Jawaharlal Nehru and his followers, who were in serious disagreement with such attitudes, and considered it a manifestation of medievalism and 'communalism'.

The Government of free India adopted an approach which was not in opposition to religion but sought the removal of religion from public affairs, the separation of state from all faiths, the insistence on religion as a private matter for the individual with no bearing on civil rights and duties. This approach was not only a part of the 'modern outlook' but also 'the most practical approach' (Gopal 1992: 13). But it was easy to proclaim a theory which posited the a priori separation between 'religion' and 'state politics' than to effect it. A cursory survey of the contentious cultural issues raised immediately after August 1947 leads us to the conclusion that when it came to the crunch Nehru could not implement these theoretical principles and there was retreat from what he had considered to be desirable action on the part of the state. Between theory and practice, we are told, fell the shadow of 'hesitancy' (Gopal 1992: 15). But slowly the sphere of this 'hesitancy' began to expand and from a set 
of principles, actively guiding state policies and interventions, these principles of secularism retreated into ideals. But wherein lay the social roots of this 'hesitancy'?

Hindu sentiment was, and continues to be, a very complex one. If one end of the spectrum of this sentiment was articulated by political organisations such as the Hindu Mahasabha and the RSS, the other end, more subtle and less sharply etched out, penetrated extensively into the Congress ranks and its mass following. It is in this sense that Patel's above quoted remark about Gandhi's assassin ("one of us") and the RSS (our brethren) needs to be understood (qtd. In R. Gandhi 1990: 496). In this context, we must point out that organisations like the Hindu Mahasabha, the RSS and the Indian National Congress operated within the same cultural internality which generated a spectrum of common cultural sentiment. Even when individuals and groups shared the same cultural sentiment they could differ widely in their strategic responses and political goals. Though he seldom spoke of secularism, Patel was no proponent of Hindu rule. In February 1949, he spoke of 'Hindu Raj' as that 'mad idea' (Gandhi 1990: 497). Nehru was not emotionally in tune with the Hindu cultural sentiment and as a result could not establish communication with considerable sections of the Hindu population. Though Sardar Patel could be located within the Hindu cultural spectrum nevertheless he opposed the notion of the Hindu state. All the same, unlike Nehru, for him it was very important to understand the depth of this sentiment, disentangling its various shades and devising an adequate response to placate, diffuse and contain it. For people like Patel, Prasad and Munshi and many others in the Congress leadership it was not to be denounced and frontally attacked as 'backwardness' and lack of 'modern outlook'. An unmitigated opposition to this sentiment without comprehending the meanings of its various shades, apart from being unwise, could also prove to be costly to the Congress in terms of political power. Thus the necessity to stay in power and the commitment to the principles of secularism were not to be counterposed but to be reconciled with the hope that the forces of modernisation would work towards the eradication of this 'narrow communalism.'

Meanwhile, against the backdrop of partition the newly emerging India was to be saved from becoming a Hindu state by neutralising as well as accommodating some of the Hindu cultural practices into the state's rituals of power, state policies and decisions. Though put on the defensive from the very beginning, the principles of secularism and the ultimate goal of creating a secular society were not to be abandoned. In fact, the state-sponsored project of secular pedagogy of the nation was to be elaborated systematically in the domain of education and mass media involving the intelligentsia in this project in a big way. If not completely eradicated, at least, the tide of 'communalism' was expected to recede and be marginalised with the forging ahead of the combined onslaught of secular ideological indoctrination and industrialisation.

The campaign to renovate the temple of Somnath had started immediately after the country attained freedom on 15 August 1947 thereby underlining the fact that for a section of the national Congress movement the cultural impulse for temple renovation was umbilically linked with the political project of India's independence. On Diwali day, on 12 November 1947, Sardar Patel accompanied by Jam Saheb and 
Kaka Saheb, Gadgil, went to Junagarh. When was the idea of the reconstruction of the temple precisely mooted? K.M. Munshi records for us the 'birth' of this idea:

We saw the temple, while Sardar and I (Kaka Saheb) were having a little walk on the beach, I said to Sardar: 'I think the Government of India ought to rebuild this temple'. He said 'Well, go ahead'. Then we two and the Jam Saheb came to the temple and there in the presence of about 500 people, I announced: 'Government of India has decided to rebuild this temple and instal the deity. This Government has come to fulfil and not to destroy. The age of reconstruction is now on'. Immediately - after this, the Jam Saheb announced a donation of one lakh of rupees. Fifteen minutes later, a huge public meeting was held in Ahalya Bai temple where Sardar in his speech, said: 'On this auspicious day of the new year, we have decided that Somanath should be reconstructed. You, people of Saurashtra, should do your best. This is a holy task in which all should participate'. Jam Saheb gave the first donation of one-lakh rupees for the construction. Samaldas Gandhi representing the Junagarh administration followed with rupees 51,000. (Munshi 61)

According to Munshi, though the Government of India sponsored the scheme, Patel decided that the government should not make any contribution in the form of money for the reconstruction of the temple. ${ }^{3}$ In 1949, Patel appealed for public contributions to rebuild the temple of Somnath (Das XXII).

Sardar Patel, K.M. Munshi and their other friends were fully aware of the meanings of the emotion associated with the reconstruction of the temple. "In the beginning', writes Munshi, some persons, more fond of dead stones than live values, pressed the point of view that the ruins of the old temple should be maintained as an ancient monument. We were, however firm in our view, that the temple of Somanatha was not an ancient monument; it lived in the sentiment of the whole nation and its reconstruction was a national pledge" (Munshi 64. My emphasis).

Clearly, there was a tussle between 'some persons' and the 'we' before the decision for reconstruction was actually taken. When the proposal for the preservation of the ruins was pressed by the Archaeological Department, Patel expressed his views:" the Hindu sentiment in regard to this temple is both strong and widespread. In the present conditions, it is unlikely that, that sentiment will be satisfied by mere restoration of the temple or by prolonging its life. The restoration of the idol would be a point of honour of sentiment with the Hindu public" (Munshi 64. My emphasis).

Apart from the construction of the Somnath temple, the other important cultural issue which agitated the minds of the Congress leadership was the issue of cow slaughter. In a lengthy letter to Nehru on 7 August 1947, Rajendra Prasad informed him that the agitation demanding a ban on cow slaughter was spreading 'with tremendous speed' and had reached 'practically all provinces and very large number of people' (Chodudhary 1987: 7/91-92). 'The Hindu sentiment in favour of cow protection is old, widespread and deep-seated... It was almost impossible to

3 This suggestion was first mooted by Gandhi at a prayer meeting on 28 November 1947. 
now ignore it.' 'I think', he Suggested 'that the matter does require consideration and, we must take a decision whatever it is after due consideration'. The Hindu feeling on account of 'recent happenings' was very much agitated, he clarified, and this movement, like the movement in favour Of Hindi, was 'bound to gain strength more rapidly than We can imagine.'

Nehru did not oppose the listing of the banning of cow slaughter as one of the directive principles of state policy in the constitution. All he did was to ensure that nothing came of it in practice (Gopaland and Parthsarthy 24). Holding out the threat of resignation was one of Nehru's ways to resist the inner party pressures. His and Savarkar's way of posing the question about the historically evolved reality — called India - was the same, though they gave contradictory answers: Was India a Hindu country? Or was it a composite country? For a large number of Congressmen and their followers it was difficult to answer the above questions in terms of a simple 'yes' or 'no.' For them the 'composite' character of the country was not irreconcilable to its 'Hindu' character. But this third choice or possibility was denied to them by Nehru and he insisted that they must face the 'logic' of their choice squarely: "we must not function as a Hindu state but as a composite state in which Hindus, no doubt predominate" (qtd in Gopaland and Parthsarthy 190-191).

But what was meant by 'composite country' and 'composite state'? Nehru never felt the need to clarify it. Not only that, he labelled it as secularism and thereby generated a discourse of ambiguity. Now multiple interpretations of secularism could contend with each other, and, over time, one of them tended to become a truism: any act or policy of the state which did not conform to the articulate opinion of the Muslim community did not qualify for being characterised as 'secular'. In practice, Nehru implemented the notion of 'composite culture' in a way which went against the very idea of common citizenship and maintained the pre-partition conception of communities being fundamentally different from each other.

The third important issue, and this was a clear blow to Nehru's notion of 'composite culture', was the issue of the language of the republic. As suggested by Mahatma Gandhi, the Committee of the Hindustani Prachar Sabha, Bombay, at its meeting held on $29^{\text {th }}$ July 1947, considered the resolution regarding Hindi with Devnagri script being adopted as the national language of India. This meeting of the Sabha adopted a memorandum which was sent to the President: 'We are very much surprised', declared the memorandum, 'to learn that the Congress Party members of the Constituent Assembly have decided that Hindi, written in Devanagri script, should be the national language of India' (Chodudhary). It noted that Mahatma Gandhi had definitely stated that Hindustani in both the scripts was the only medium through which millions of Indians could be brought together. The Sabha felt that it would be 'a disastrous blow to the cause of national unity and harmony if leading Congressmen take a narrow and communal point of view.' It warned the Congress that the decision to make Hindi as the national language would be an act of 'violation of the Congress Constitution and 'suicidal to the national spirit and tradition of the Congress.'

On the question of Hindi-Hindustani, in his letters to concerned friends, Nehru said frankly that the move to oust Hindustani was unfortunate and unde- 
sirable. 'I have been trying to combat it, not with great success I am sorry to say. Unfortunately this partition business has roused passions among the Hindus and they are acting in a narrow short-sighted way in many respects.' (Nehru 1987: 3/186).

The Congress Party, under the psychological pressures generated by the partition, was reflecting trends which were very unpalatable to Nehru. 'All of us', he told Mohanlal Saxena in September 1949, 'seem to be getting infected with the refugee mentality or worse still, the RSS mentality. This is a curious finale to our careers.' If, on the one hand, both Bidhan Roy and Patel were suggesting the expulsion of 'equal number of Muslims from Bengal' as a retaliatory measure against the East Bengal Government's policy of forcing the Hindus to migrate, on the other, P.D. Tandon in Uttar Pradesh was calling upon the Muslims to adopt 'Hindu culture' (Gopal 2: 92). 'Communalism has invaded the minds and hearts of those', Nehru wrote to G.B. Pant in April 1950. 'who were pillars of the Congress in the past. It is a creeping paralysis and the patient does not even realise it' (Gopal 2: 92). Even after Partition, Nehru as an individual continued to uphold the original separation between 'culture' and 'politics' as propounded by the discourse of nineteenth century Congress liberals.

Was the Congress turning into a communal organisation as asserted by Nehru? No. What was happening was that large number of Congressmen were finding it difficult to maintain the strict division between 'culture' and 'politics' as required by the Nehruvian discourse of secularism. Because, in their heart of hearts, many were equally convinced that the Congress now could and should legitimately reflect the cultural pride of the Hindus without having pangs of guilty conscience. In their eyes, having a legitimate pride in one's own cultural traditions was very much a part of nationalism, i.e., 'cultural nationalism', and 'political nationalism' went hand-in-hand with it. But once the cultural aspirations were driven underground in the name of 'communalism' the Congress could not possibly be an adequate vehicle for their expression. Before the Partition many of these Congressmen could understand the rationale of keeping the discourse of 'culture' underground as the pragmatic need of the Congress policy of uniting with the Muslims demanded this. But now they could not but have perceived such attitudes as self-imposed censorship.

Under Nehru, Congress as an organisation ceased to become a vehicle of Hindu cultural identity. People like Shyama Prasad Mukherjee, the erstwhile President of the Hindu Mahasabha, realised that for people like him, there was no place in the Congress. This was the background which gave birth to an organisation such as the Jana Sangh (Baxter 1971; Graham 1990). But the problem with such a party was, and continues to be even today in its form as the Bharatiya Janata Party, that it could not evolve a more radical social programme of national development as compared to the Congress. Beyond a particular point, as we know, the cultural issues of identity begin to be intertwined with caste and class issues and power relations between those who are mobilised in the movement. Therefore the birth of Jana Sangh, purely on a programme of cultural identity, further deepened, though unwittingly, the party division in the spectrum of Hindu cultural nationalism. The moderate complex of Hindu identity continued to stay underground within the Congress while the strong voices came to be articulated through the Jana Sangh. 
The very logic of formation of a new political party dictated that if it was to acquire a position of power then it must claim to be the 'sole spokesman' of Hindu identity. It should make use of the Congress's inability to compete with it by accusing it as a party of the cultural minorities.

In fact, at moments, even for Nehru it was difficult to not mix cultural mythologies with secular politics. After the war with China Nehru was to assert that India's frontier was traditional and was associated with 'India's culture and tradition' (Embree 67). A White Paper prepared by the Historical Division of the Ministry of External Affairs quoted from the Vishnu Purana to support the argument that the country south of the Himalayas and north of the Ocean is called Bharat and 'all born in it are called Bharatiyas or Indians'. Similar references were given from Rig Veda, Mahabharata, Ramayana and other Sanskrit texts pointing to the cultural and political unity of India.

Against the backdrop of the partition and the formation of Pakistan as a separate state demanded in the name of Indian Muslims, the newly independent Indian state was faced with a dilemma. Was it to continue with the imperial model of secularism and act as an arbiter between various cultural and religious communities of India? Obviously, the question was to be decided by the newly unleashed ideological tendencies within the country, especially within the Indian National Congress, which had taken over the state and formed the new government. As the later history of ideological/political struggle within the Congress was to show, none of the two contending currents was in a position to completely defeat and marginalise the other. Through their struggle, they came to circumscribe and limit the influence of each other on administration and the policies of the state. Therefore, the on-going battle for imparting a cultural complexion to the nation-State turned out to be a long drawn and complicated one. After the death of Patel and the political withdrawal staged by Tandon, Nehru had succeeded in establishing an ideological equilibrium within the country which was to be favourable to the forces led by him under the banner of secularism. This did not mean that the problem of cultural issues had been resolved. But he did succeed in removing what he called communal issues from the national agenda, and replaced them with a developmental agenda of economic progress, industrialisation and modernisation.

The censorship on the articulation of Hindu cultural sentiment imposed by Nehru created a split between the 'emotional make-up' and 'intellectual makeup' in the lives of a large number of Congressmen. Therefore, the 1950 Presidential election of the Indian National Congress, between P.D. Tandon and Acharya Kripalani, was primarily a struggle which embodied the logic of this 'split'. The alliance between Patel and Tandon should be looked upon as an attempt to seek recognition and respectability for the Hindu cultural identity within the official Congress discourse by underlining the fact that the Nehruvian view of agnostic spirituality was not acceptable to a large number of Congressmen. Paul Brass sums up the complex nature of this 'split':

Most Congressmen in Uttar Pradesh accepted both Nehru and Tandon as their leaders and saw no incompatibility between them. Congress in Uttar Pradesh intel- 
lectually recognised and accepted most of Nehru's political ideas as necessary for the development of the country, but it was Tandon who appealed to the emotional identification of Congressmen in Uttar Pradesh with their language, their culture, and their religion. (Brass 87; cfr.Weiner ch 4).

Nehru and many of his followers were embarrassed and mortified by the mention of a thing called 'Hindu sentiment'. Actually this "split" was not and is not a simple one. Its complex composition embodies within it the impact of westernisation on the educated classes, especially, among the Hindus. In fact an unself-conscious maintenance of this 'split' is held by the westernised intellectualls to be central to the very definition of a modernized liberal individual. For many of them to uphold secularism and modernity is to uphold the psychological frame which denies the cultural needs of the 'emotional make-up'.

In the aftermath of the Emergency, when the cultural ideologues of Hinduism sought to turn this psychological 'split' into a 'sharp ideological contradiction by focusing the mass attention on the Congress' practice of secularism, Mrs. Gandhi began to vacillate between the two poles. On the one hand, she added the words 'secular' and 'socialist' to the Preamble of the constitution by the 42nd Amendment Act, $1976^{4}$, while, on the other, she tried to win over the Hindu opinion by going to temples and sometimes even incorporating into her speeches and gestures parts of their discourse. This policy of vacillation was continued by Rajiv Gandhi, thereby, sending a public message that the Congress was being assailed by doubts and no longer confident when faced with the challenge to its professed ideology of secularism.

Historically speaking, the Congress has remained in power by adjusting and representing three sociological codes of mass consciousness, i.e., caste, class and community. Its encompassing vision of developmental nationalism cut across these sectional codes in order to bind them together into a unity. Unlike the Congress, the opposition groups/parties have derived their strength from more or less one of these single codes while simultaneously flirting with other codes, especially the code of nationalism and regionalism. This has split the opposition into three rivulets: Communist parties (class code), groups based on Lohia brand of ideology (caste code) and Jana Sangh or BJP (community code). But these codes, however important characteristics they might be of Indian social reality, in themselves cannot offer national level alternatives. Not only that, these codes cannot even unite without a political group which brings to bear upon these sectarian codes the overarching code of nationalism. This leads us to the conclusion that without the presence of the BJP-type party, which inherited the Hindu nationalism of Savarkar and S.P. Mukerjee, no alternative governments to the Congress could have come into being. Despite their best intentions anti-Congress tendencies cannot but lead the 'caste' and 'class' codes towards an open or tacit alliance with the ideologues of

${ }^{4}$ The fateful word 'Secularism' did not exist in the Constitution of India before 1976. The Indian Constitution is imbued with the spirit of non sectarianisms but to call it 'Secular' would be misnomer. In order to paper over this ambiguity many began to call "Indian Secularism." 
sectarian Hindu nationalism. The 'caste' and 'class' codes of mass consciousness are faced with a permanent dilemma. They are forced to incline towards the BJP in their search for an alternative to the Congress while their desire to uphold developmental and egalitarian perspectives pulls them towards the Congress.

If this is accepted as a realistic appraisal of contemporary Indian politics then the real struggle is, and continues to be, between organisations engaged in defining and redefining the nature of Indian nationalism through the actual mobilisation of the people on 'national issues' and not on 'caste' or 'class' issues. As this struggle sharpens the codes of 'caste' and 'class' would be under pressure to align with one side or the other. The politics of 'caste' and 'class' are forms of politics in this country that can be adjusted but they remain limited within the overarching umbrella of nationalism. Indian nationalism has always overlapped with Hindu cultural sentiment though the forms of its articulation have varied from time to time. Today, the struggle to convert Gandhian nationalism into a Savarkarite nationalism and its search for mass articulation is going to define the nature of the nation-state in the years to come.

The imposition of Emergency proved to be a golden opportunity for the forces representing Savarkarite nationalism. For the first time, this helped them to champion the cause of democracy, get rid of their status of being political untouchables, and to a considerable extent erase the stigma of sharing the ideology which had inspired the killer of the Mahatma. From a position of political marginality, their secular allies (caste and class codes) helped them to place themselves in mainstream politics. Moreover, the Emergency had robbed the main secular party of its moral legitimacy thereby reducing it to the status of 'one of the many political parties'. Ironically, it was the opportunity provided by Mrs. Gandhi and the help rendered by the anti-Congress opposition which placed the votaries of Hindutva in the centre stage.

Mrs. Gandhi's debacle in 1977 owed a great deal to the alienation of both Muslims and Harijans from the Congress who, however, rallied to her support again in 1980. What happened during the Emergency, and the Hindu-Muslim killings in the early months of 1980 which had once again erupted in full fury, strained the relationship between her and considerable sections of the Muslim community. The communal strife at Moradabad lasted a whole month, taking a toll of 144 lives. Many of her critics have noted that for the first time in her political career, Indira Gandhi departed from the normal style of rushing to the scene of every major communal conflagration to condole with the bereaved. Though Moradabad was only a few minutes away from Delhi by helicopter, she just would not go there despite appeals by secular parties and groups. Was Mrs. Gandhi no longer interested in continuing the Congress's special relationship with the Muslim community? It is possible, that in the contest for cultural hegemony between the communities she may have wanted to be perceived as neutral. But her attempt to acquire a position of neutrality by correcting the 'historic tilt' could not but have been perceived by interested quarters as an attempt, however belated, to move in the direction of recognising and taking note of the rising wave of Hindu sentiment. Many had begun to read into her 'words' and 'departures' an effort at pandering to Hindu critics who 
had long grumbled that she, like her father, tended to 'pamper' Muslims and other minorities at the cost of the Hindu majority.

Rajiv Gandhi's case was simple. Being a naive modernist free from the burden of accumulated national experience he saw nothing wrong in doing contradictory things so long as his moves helped him to buy peace. He seemed to be totally unaware of the fact that developments in Kashmir and Punjab had stirred up deeper anxieties and memories of partition in large sections of the Hindu population. The Hindu community had begun to look upon these developments as a serious challenge to 'its' state. Caught in the cleft of cultural contest between the communities to influence the political complexion of the nation-state he first thought of pleasing the dominant Muslim opinion by staging a retreat on the Shah Bano Case. Once the other side reacted to this move very sharply, he now thought of unlocking the Babri Masjid thereby recognising and legitimising what had been considered till date as something disputable. Was it a conscious strategic move to recognise and incorporate the Hindu sentiment within the Congress discourse in order to outmanoeuvre the BJP combine? Or, was it just a thoughtless surrender? From the outset, the emergence of an aggressive Hindu cultural sentiment in the 1970s was considered by the BJP combine as its political monopoly.

Narasimha Rao's declaration from the Red Fort that the Congress was in favour of constructing a grand temple at Ayodhya, brought home the idea that the Congress, notwithstanding the constraints of its secular ideology, was actually competing with them to articulate the newly emerged and fast consolidating Hindu sentiment. Would they allow the Congress to outmaneuver them at this advanced stage? The question began to slowly sink into the minds of the BJP leadership and' of its cadre. This led many amongst them to a different conclusion: the rules of the 'game' were heavily loaded against them and the Congress would not allow them to occupy the seat of power so long the 'game' was played within the rules. Hence the rules of the 'game' must be changed. And this they did on $6^{\text {th }}$ December 1992 by demolishing the Babri mosque.

India can never be the same again.

Reviews sent to author: 16 November 2017 Revised paper accepted for publication: 27 February 2018 


\section{REFERENCES}

“Old obsessions: Government must refuse call to institute temple at masjid site to avenge Godhra." The Times of India, 8 December 2017. https://blogs.timesofindia.indiatimes.com/toi-editorials/ old-obsessions-government-must-refuse-call-to-institute-temple-at-masjid-site-to-avengegodhral. Accessed 20 February 2018.

Brass. Paul. Factional Politics in an Indian State: Uttar Pradesh. Bombay, 1966.

Chodudhary, Valmiki ed. Dr.Rajendra Prasad: Correspondence and Documents. https://archive.org/ details/in.ernet.dli.2015.463267.

Baxter, Craig. The Jana Sangh: A Biography of a Indian Political Party. Oxford University Press, 1971.

DAs, Durga ed. Sardar Patel: Correspondence. Ahmedabad, 1973.

Desai, Meghnad. “Out of my mind: Does it matter?” The Indian Express, 3 December 2017. http:// indianexpress.com/article/opinion/columns/rahul-gandhi-gujarat-assembly-elections2017-out-of-my-mind-does-it-matter/. Accessed 20 February 2018.

Embree, Ainslie T. Imagining India: Essays on Indian History. Oxford University Press, 1989.

Gandhi, Mohandas K. Collected Works. Ganshi Serve Foundation. http://gandhiserve.org/e/cwmg/ cwmg.htm.

Gandhi, Rajmohan Patel: A Life. Navjivan, 1990.

GANESH, Narayani. " Nations are lines in the sand, tomorrow they may not be there ... why would you give up your life for that?” "The Times of India, 13 October 2017. https://blogs.timesofindia. indiatimes.com/treasurehunt/nations-are-lines-in-the-sand-tomorrow-they-may-not-bethere-why-would-you-give-up-your-life-for-that/. Accessed 20 February 2018.

Godse, Nathu Ram. “Why I Assassinated Gandhi?” Forsight Publishers and Distributors, 1948.

Golwalkar, M.S. We OR Our Nationhood Defined, Nagpur, 1947 (1939).

Gopal, Sarvepalli. Jawaharlal Nehru: A Biography. 3 vols. Oxford University Press, 1979.

- Anatomy of a Confrontation: Ayodhya and the Rise of Communal Politics in India. Zed, 1992.

Gopaland, S. and G. Parthasarthy. Jawaharlal Nehru and India's Quest for a Secular Identity. Nehru Memorial Museum and Library, Occasional Paper No. XII, May 1987.

Graham, B.D. Hindu Nationalism and Indian Politics: The Origins and Development of the Bharatiya Jana Sangh, Cambridge University Press, 1990.

JosH, Bhagwan. "Conversions, complicity and the state in post-Independent India", in Julius Bautista and Francis Khek Gee Lim eds. Christianity and the State in Asia, Routledge, 2009, pp. 97-115.

Joshi, Shashi and Bhagwan Josh. Struggle for Hegemony in India. 3 vols. Sage. 1994.

- A History of the Indian Communists: A Critique of the Discourses of Communalism and Secularism. Sage, 3 vols., 2013.

Munshi, K.M. Jaya Somanatha: The Shrine Eternal, Bombay, 1952.

Nehru, Jawaharlal. Selected Works (New Series). Oxford University Press, 1987.

Weiner, Myron. Party Politics in India: The Development of a Multiparty System, Princeton, 1957. 
